Eriksson, A. W., Fellman, J., Vainio-Mattila, B., Sanger, R., Race, R. R., Krause, V., and Forsius, H. (1969). Studies on X-linked retinoscisis in Finland. In Progress in Neuro-ophthalmology, pp. 360-362, Proceedings of the 2nd International Congress on Neuro-genetics and Neuro-ophthalmology, Montreal, 1967, ed. by A. Barbeau and J. K. Brunette, Excepta Medica International Congress Series, No. 176, Amsterdam.

Falls, H. F. (1951). Sex-linked ocular albinism displaying typical fundus changes in the female heterozygote. American fournal of Ophthalmology, 34, 41-50.

Falls, H. F. and Cotterman, C. W. (1948). Chorioretinal degeneration. Archives of Ophthalmology, 40, 685-703.

Fialkow, P. J., Giblett, E. R., and Motulsky, A. G. (1967). Measurable linkage between ocular albinism and Xg. American fournal of Human Genetics, 19, 63-69.

Grüneberg, H. (1967). Sex-linked genes in man and the Lyon hypothesis. Annals of Human Genetics, 30, 239-257.

Johnson, G. J., Gillan, J. G., and Pearce, W. G. (1971). Ocular albinism in Newfoundland. Canadian fournal of Ophthalmology, 6, 237-248.

Klein, D., Franceschetti, A., Hussels, I., Race, R. R., and Sanger, R. (1967). X-linked retinitis pigmentosa and linkage studies with the Xg blood groups. Lancet, 1, 974-975.

Krill, A. E. (1967). Observations of carriers of X-chromosomallinked chorioretinal degenerations. American fournal of Ophthalmology, 64, 1029-1040.

Lyon, M. F. (1961). Gene action in the X-chromosome of the mouse (Mus Musculus L.). Nature, 190, 372-373.

Lyon, M. F. (1962). Sex chromatin and gene action in the mammalian X-chromosome. American fournal of Human Genetics, 14, 135-148.

McCulloch, J. C. and McCulloch, R. J. P. (1948). A hereditary and clinical study of choroideremia. Transactions of the American Academy of Ophthalmology-Otolaryngology, 52, 160-190.

Pearce, W. G., Sanger, R., and Race, R. R. (1968). Ocular albinism and Xg. Lancet, 1, 1282-1283.

Sabates, F. N. (1966). Juvenile retinoschisis. American fournal of Ophthalmology, 62, 683-688.

Vogt, A. (1925). Úber Maculalosigkeit bei isoliertem Bulbusalbinismus als geschlechtsgebunden-rezessive Merkmal. Archiv der Julius Klaus-Stiftung für Vererbungsforschung Sozialanthropologie und Rassenhygiene, 1, 119-122.

Vogt, A. (1942). Die Iris bei Albinismus solum bulbi. In Atlas für Spaltlampen-Mikroskopie, vol. 3, pp. 846-847. Enke, Stuttgart.

Waardenburg, P. J. (1970). Remarkable Facts in Human Albinism and Leukism, p. 55. Van Gorcum, Assen.

Waardenburg, P. J. and Bosch, J. van den (1956). X-chromosomal ocular albinism in a Dutch family. Annals of Human Genetics, 21, 101-122.

Weiner, R. L. and Falls, H. F. (1955). Intermediate sex-linked retinitis pigmentosa. Archives of Ophthalmology, 53, 530-535.

\section{A Duarte Variant with Clinical Signs}

Patients with the Duarte variant of galactosaemia are usually healthy, despite functional and structural abnormalities in their galactose-1phosphate uridyl transferase (Beutler et al, 1965; Mathai and Beutler, 1966; Gitzelman, Poley, and Prader, 1967; Ng et al, 1969). We describe an infant with abnormal signs associated with the enzyme phenotype of a homozygous Duarte variant.

Received 20 July 1971.

\section{Case Report}

A 2-month-old boy was admitted to the hospital because of jaundice since the 3 rd day of life.

The pregnancy and delivery were normal. He weighed $3.2 \mathrm{~kg}$ at birth, was $52 \mathrm{~cm}$ long, and had a head circumference of $34 \mathrm{~cm}$. Apgar scores were 9 at 1 minute and 10 at 5 minutes. Physical examination after birth was normal. He was blood group $\mathrm{O}$, type $\mathrm{Rh}$ positive, as was his mother. His diet from birth was Enfamil, which he tolerated well. $\mathrm{He}$ was slightly jaundiced when discharged from the nursery on the 3rd day; the liver edge was $1 \mathrm{~cm}$ below the right costal margin.

He continued to gain, in spite of mild jaundice apparent at office visits at 11 days and 6 weeks of age. The total serum bilirubin concentration at 6 weeks was $3.9 \mathrm{mg} / 100 \mathrm{ml}$, of which $3.6 \mathrm{mg} / 100 \mathrm{ml}$ was in the conjugated (direct reading) form. The jaundice deepened, and the weight gain lessened during the 2 weeks before admission.

He was the 2nd child of healthy, unrelated, 23-yearold parents. His 3-year-old sister had been well as an infant, and there was no history of milk intolerance, jaundice, or liver disease in the family.

He was icteric on admission. The liver was felt $4 \mathrm{~cm}$ below the right costal margin; the spleen was not felt. Two veins were prominent in the right upper quadrant. He had signs of a cold. Weight $(4.5 \mathrm{~kg})$ and length $(55 \mathrm{~cm})$ were in the 25 th centile; head circumference $(37.5 \mathrm{~cm})$ was in the 10 th centile. Motor development was normal.

Total serum bilirubin concentrations on consecutive days were 5.7 and $7.4 \mathrm{mg} / 100 \mathrm{ml}, 3.6$ and $3.4 \mathrm{mg} / 100 \mathrm{ml}$ of which, respectively, were in the conjugated (direct reading) form. The white cell count was 19,650 cells/ $\mathrm{mm}^{3}$, with a lymphocytosis of $85 \%$. Red cells values were normal and included a haemoglobin concentration of $12.6 \mathrm{~g} \%$, hematocrit of $38.5 \%$, and reticulocyte count of $1.6 \%$. The urinalysis was normal; reducing sugars were not detected. Faecal and urinary urobilinogen, throat and urine cultures, serum protein electrophoresis, and serum enzymes were normal, except for $282 \mathrm{mU} / \mathrm{ml}$ of serum glutamic-oxaloacetic transaminase.

A diagnosis of biliary atresia was considered. Other abnormalities found a few days later during evaluation for surgery in another hospital were: a palpable spleen, $1 \frac{1}{2} \mathrm{~cm}$ below the left costal margin; dark, bile-stained urine with excessive urobilinogen; an acholic stool; an elevated, rising aldolase concentration; hematocrit values ranging from 28 to $36 \%$ and reticulocytosis of up to $6.2 \%$. The serum bilirubin concentration remained $5.0 \mathrm{mg} / 100 \mathrm{ml}$, of which $3.6 \mathrm{mg} / 100 \mathrm{ml}$ was in the conjugated form. A radioactive rose bengal test suggested but did not confirm an obstruction.

Surgery exposed a green, non-fibrotic liver and an unusually small, bile-containing gallbladder, which was incised, drained, and irrigated. An operative cholangiogram revealed patent ducts and normal flow. The consulting pathologist described 'marked fatty infiltration, bile retention, periportal fibrosis (and cirrhosis) and 
pseudoacinar changes' in liver biopsy material and suggested a diagnosis of galactosaemia.

The jaundice faded gradually, and the total bilirubin fell to $1.2 \mathrm{mg} / 100 \mathrm{ml}$ within 3 weeks. He was then 3 months old, with weight and height in the 25 th, and head circumference in the 10th centiles. The liver was $4 \mathrm{~cm}$ below the costal margin; the spleen was not enlarged. Motor and mental development were normal.

The infant continued to thrive, except for acute asthmatic bronchitis requiring hospitalization at $4 \frac{1}{2}$ months, by which time the jaundice was gone, and the serum bilirubin concentration $(0.3 \mathrm{mg} / 100 \mathrm{ml})$, haemoglobin $(13.8 \mathrm{~g})$ and reticulocyte count $(0.5 \%)$ were normal. The levels of serum alkaline phosphatase and glutamic-oxaloacetic transaminase, however, were higher than normal.

At 9 months his weight $(10.2 \mathrm{~kg})$ and height $(72 \mathrm{~cm})$ were in the 75th centile; his head circumference $(44 \mathrm{~cm})$, was in the 10th centile. The anterior fontanelle was open. The liver and spleen were not enlarged. Motor development and behaviour were normal. He has been fed whole milk from the age of 5 months.

\section{Methods and Materials}

When the patient was 8 months old, we measured the galactose-1-phosphate uridyl transferase in mailed heparinized samples of his blood and that of his parents and sister by fluorescent spot tests (Beutler and Baluda, 1966a) and by fluorometric assays (Beutler and Mitchell, 1968). Transferase activities were again estimated when the boy was 9 months old, this time in fresh samples cooled to $4^{\circ} \mathrm{C}$ during transit and measured by a uridine-5-diphosphoglucose (UDPG) consumption method (Beutler and Baluda, 1966b). Comparable data from 6 healthy adults, aged 20 to 50 years, and from the literature (Beutler and Baluda, 1966b) served as control values. We separated the isozymes by horizontal electrophoresis of the hemolysates through starch gel for 18 hours at $4{ }^{\circ} \mathrm{C}$ in a continuous buffer system of Tris, ethylenediamine tetra-acetic acid, sodium chloride, and

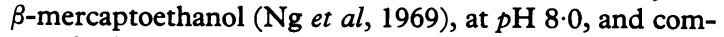
pared them with the normal transferase and with Duarte variant transferase from Dr Ernest Beutler's patients.

\section{Results}

Transferase activities in the mailed blood samples were normal, when estimated by the fluorescent spot tests, ie, fluorescence times were similar to those from normal infants (Kelly et al, 1970). Measured by fluorometry, however, there was less transferase than expected (Table), especially in the patient. Transferase in the fresh samples, measured by UDPG consumption, also reflected the lower activities: The patient's enzyme levels were approximately half and the parents' and sister's levels, threefourths those in normal blood.

The isozyme in the patient's hemolysate had the
TABLE

GALACTOSE-1-PHOSPHATE URIDYL TRANSFERASE IN THE PROPOSITUS AND HIS FAMILY

\begin{tabular}{|c|c|c|c|c|c|}
\hline \multirow{5}{*}{ Sample } & \multicolumn{5}{|c|}{ Galactose-1-phosphate Uridyl Transferase } \\
\hline & \multicolumn{4}{|c|}{ Activity } & \multirow{4}{*}{$\begin{array}{l}\text { Isozyme } \\
\text { Genotype }\end{array}$} \\
\hline & \multicolumn{3}{|c|}{ Units/g Haemoglobin } & \multirow{3}{*}{$\begin{array}{l}\text { Fluorescence } \\
\text { Time (hr) }\end{array}$} & \\
\hline & \multicolumn{2}{|c|}{ Fluorometry } & \multirow{2}{*}{$\begin{array}{c}\text { UDPG } \\
\text { Consump- } \\
\text { tion }\end{array}$} & & \\
\hline & Test a & Test b & & & \\
\hline $\begin{array}{l}\text { Patient } \\
\text { Father } \\
\text { Mother } \\
\text { Sister } \\
\text { Controls }\end{array}$ & $\begin{array}{c}6 \cdot 5 \\
12-15^{*}\end{array}$ & $\begin{array}{l}7 \cdot 4 \\
11 \\
10 \\
10\end{array}$ & $\begin{array}{c}12 \cdot 6 \\
17 \cdot 0 \\
15 \cdot 0 \\
15 \cdot 0 \\
18 \cdot 5-28 \cdot 5 t\end{array}$ & $\begin{array}{l}<3 \\
<3 \\
<3 \\
<3 \\
<3\end{array}$ & $\begin{array}{l}\mathrm{Gt}^{\mathrm{D}} / \mathrm{Gt}^{\mathrm{D}} \\
\mathrm{G} \mathrm{t}^{\mathrm{D}} / \mathrm{Gt}^{+} \\
\mathrm{Gt}^{\mathrm{D}} / \mathrm{Gt}^{+} \\
\mathrm{Gt}^{\mathrm{D}} / \mathrm{Gt}^{+} \\
\mathrm{Gt}^{+} / \mathrm{Gt}^{+}\end{array}$ \\
\hline
\end{tabular}

* Six healthy adults.

† From Beutler and Baluda (1966a and b).

electrophoretic pattern of the Duarte homozygote, ie, a single band which moved faster than normal transferase. The isozymes in the parents' and sister's haemolysates were characteristic of those in the Duarte variant carrier, ie, 2 bands with mobilities of normal and Duarte variant transferases, respectively.

\section{Discussion}

Our patient's history suggests that even 'harmless' variants of galactose-1-phosphate uridyl transferase may be symptomatic. Thus, variable expressivity may be a property of the mutant gene for the Duarte variant transferase, as for classical galactosaemia. While the transferase defect may not be the primary or only cause of the jaundice (and, indeed, its recession during recovery from surgery is puzzling), the report of characteristic liver pathology complements the abnormal biochemistry. Conversely, the two recent reports of affected infants with other structural variants of the transferase attest the biochemical variability of the disease (Shapiro and Kaplan, 1969; Chacko, Christian, and Nadler, 1971).

Excluding the possibility of enzyme mosaicism, where the transferase of liver may differ from that of red cells, a likely explanation for the transient clinical signs in our patient is a delayed maturation of the Duarte variant transferase, as may happen occasionally in the infant heterozygote of classical galactosaemia (Kelly et al, 1970).

\section{Summary}

Galactose-1-phosphate uridyl transferase with the activity and electrophoretic pattern of the Duarte variant homozygote was found in an 8-month-old 
boy who had jaundice and liver enlargement during the first 2 months. The parents and sister were carriers of the Duarte trait.

We are very grateful to Dr James W. Sayre, Dr Thomas C. Putnam, and Dr John M. Craig for their medical, surgical, and pathological records, respectively.

Sally Kelly, Lucille Desjardins, and S. Ali KHERA

The New York State Department of Health, Birth Defects Institute, Albany, New York and the Corning Hospital, Corning, New York, USA

\section{REFERENCES}

Beutler, E. and Baluda, M. C. (1966a). A simple spot screening test for galactosemia. fournal of Laboratory and Clinical Medicine, 68, 137-141.
Beutler, E. and Baluda, M. C. (1966b). Improved method for measuring galactose-1-phosphate uridyl transferase activity of erythrocytes. Clinica Chimica Acta, 13, 369-379.

Beutler, E., Baluda, M. C., Sturgeon, P., and Day, R. (1965). A new genetic abnormality resulting in galactose-1-phosphate uridyl transferase deficiency. Lancet, 1, 353-354.

Beutler, E. and Mitchell, M. (1968). New rapid method for the estimation of red cell galctose-1-phosphate uridyl transferase activity. Fournal of Laboratory and Clinical Medicine, 72, 527-532.

Chacko, C. M., Christian, J. C., and Nadler, H. L. (1971). Unstable galactose-1-phosphate uridyl transferase: A new variant of galactosemia. Fournal of Pediatrics, 78, 454-460.

Gitzelmann, R., Poley, J. R., and Prader, A. (1967). Partial galactose-1-phosphate uridyl transferase deficiency due to a variant enzyme. Helvetica Paediatrica Acta, 22, 252-257.

Kelly, S., Katz, S., Burns, J., and Boylan, J. (1970). Screening for galactosemia in New York State. Public Health Reports, 85, 575578.

Mathai, C. and Beutler, E. (1966). Electrophoretic variation of galactose-1-phosphate uridyltransferase. Science, 154, 1179-1180.

Ng, W., Bergren, W. R., Fields, M., and Donnell, G. N. (1969). An improved electrophoretic procedure for galactose-1-phosphate uridyl transferase: demonstration of multiple activity bands with the Duarte variant. Biochemical and Biophysical Research Communications, 37, 354-362.

Shapiro, F. and Kaplan, J. C. (1969). Electrophoretic abnormality of galactose-1-phosphate uridyl transferase in galactosemia. Biochemical and Biophysical Research Communications, 35, 451-455. 